\title{
Fasting in Islam: A Combination of Spiritual Elevation and Prevention of Diseases
}

Muhammad Muzaffar Ali Khan ${ }^{1,2,3}$, Noraisha M.Nor ${ }^{1}$, Nik Mazlan Mamat ${ }^{1}$, Nor Azwani Mohd-Shukri ${ }^{1}$ and Wan Azdie Mohd Abu Bakar ${ }^{1}$

${ }^{1}$ Department of Nutrition Sciences, Kulliyyah of Allied Health Sciences, International Islamic University Malaysia Kuantan

${ }^{2}$ Non Communicable Diseases Research Unit, Kulliyyah of Medicine, International Islamic University Malaysia Kuantan

${ }^{3}$ International Institute for Halal Research and Training (INHART), E5 2-2, Level 2, Block E5, Kulliyyah of

Engineering, International Islamic University Malaysia Gombak

\section{ABSTRACT}

The obligatory fasting of Ramadan is not only an Islamic ritual to enhance the God-consciousness (called Taqwa), it may also lead to improvement of health status of fasting person(s). In other words, it is a complete overhauling instrument of Muslims soul/body in terms of faith and health. This can be termed as "Islamic fasting: a combination of spiritual elevation and prevention of diseases". During fasting Muslims try to maintain integrity of the human body both physically and spiritually. It not only keeps us healthy physically/spiritually but also makes us healthy in social obligations. Furthermore, with full devotion it brings long-lasting changes in the individual's life and relate to the level of righteousness and strength of character to resist desires. In health fasting plays an important role, for example the improvement of hyperlipidemia, obesity (fat loss), diabetes, cognition, cell functions, immunological factors, inflammation, stress and lifespan etc. This article is an effort to review and discuss research carried out on the listed conditions during the holy month of Ramadan on various aspects of human health.

KEYWORDS: fasting, cognition, white blood cells, lipid profile

\section{INTRODUCTION}

Ramadan fasting is an obligation on every healthy male and female individual when they reach puberty (adulthood). Apart from the religious obligation, it is an integral part of the culture where dining together at Iftar is common around the world in Muslims communities. During this month there is complete abstention (restrain) from food, sex, vulgarity or lies and even evil thinking etc. The fasting is said to be of all organs of the bodies like stomach remain without food, tongue is used for good speaking or recitation (Zikar-eAllah), hands are used for good, eyes are used for good things to see, feet are used to walk for good deed, brain is used for good thinking. The main objective of this article is to report and discuss research carried out during the holy month of Ramadan on various aspects of human health. However, it would be worthwhile to mention a few other aspects prior to discussing the health implication of Islamic fasting.

Corresponding author:

Muhammad Muzaffar Ali Khan Khattak

Department of Nutrition Sciences,

Kulliyyah of Allied Health Sciences,

International Islamic University Malaysia,

Jalan Sultan Ahmad Shah,

25200 Kuantan, Pahang, Malaysia

Email: muzaffar@iium.edu.my
The Islamic Fasting

When one thinks about fasting whether or not he/ she believe in Islam, a few questions appear in one's mind and these may be 1) what is the philosophy of fasting? 2) Why are we required to fast? 3) What are the social implications? 4) What are the spiritual implications? and 5) what are the health implications? If not all of these, at least one of these questions certainly appears in mind at any stage of life. The explanations to these questions require a certain depth of Islamic knowledge. However, in this article the authors would like to present their understanding/studies on the Islamic fasting for the posed questions.

\section{What is the philosophy of fasting?}

The brief answer to this is to maintain the integrity of the human body both physically and spiritually. We are the creation of Allah and He SWT prescribed it for us to do so (fast in the month of Ramadan). This can be illustrated best with an example of a machine, the manufacturer prescribe a timetable for servicing and maintenance of a machine. If this prescribed timetable is not followed, a machine can get problems earlier than the expected time. Therefore, the machine owner suffer and not the machine manufacturer. Similar is the case of Islamic fasting the humans suffer not (Allah SWT). However, this answer is not sufficient to the philosophy of Islamic fasting as it encompasses many other aspects which are beyond the capacity of the author's knowledge, the things which are not apparent to an ordinary human. 


\section{Why are we required to fast?}

As mentioned earlier, to keep ourselves healthy we need to follow the Creator's Prescription. Therefore, it is to keep ourselves healthy and fit by observing the Islamic fasting as desired by The Allah SWT.

\section{What are the social implications?}

To be healthy for one is not sufficient; it is required to be healthy in social obligations as well. Fasting is not merely abstention from food/drinks but is the feeling and sharing with those who are less fortunate. Therefore, it is to show sympathy/share with the less fortunate, to avoid selfishness and to increase the level of collective consciousness. This will route out the evil of exploitation of the poorer.

\section{What are the spiritual implications?}

Fasting with full devotion bring long-lasting changes in the individual's life and relate to 'Taaqwah' (level of righteousness). The spiritual health of individuals reflects the wholesomeness and it depends on the level of righteousness. The level of righteousness increases with complete fasting which is not only from food/drinks but a complete abstention from social evils, sex, vulgarity, lies, and evil thinking etc. The Arabic word 'Taaqwah' refers to the level of righteousness, God consciousness, God fearing, piety, and selfrestraining ${ }^{1}$. Human desires are multiple including violence, addiction, gambling/haram earnings, sex, etc. and failures to resist these desires are sins. This can only be avoided with strength in character due to which he/she overcome on these listed desires which are more often termed as Nafs, on the contrary, if strength in character does not exists then one become a slave of desires (Nafs). ${ }^{2}$ This implies that the root cause of all sins committing is due to the individual's inability to control his/herNafs. To receive the spiritual benefits of fasting, we should maintain our righteousness and refrain from any behavior that may disrupt the positive growth of our souls by observing true fasting. In one of the hadith, Prophet Mohammad (Peace Be upon Him) has said "If one does not give up falsehoods in words and actions, God has no need of him giving up food and drink". In short, Allah does not need our fasting; it is we who need the benefits of fasting to attain salvation.

\section{What are the health implications?}

The effects of the fasting are enormous in terms of spirituality, morality and physical health status of the fasting individuals. These effects have been studied by various people on the fasting adults in the Muslim communities. The effects of Islamic fasting have been reported in literature to be on well-being, spirituality, health (including, body composition, energy intakes/restrictions, hyperlipidemia, obesity (fat loss), diabetes, body/ cellular functions, immunity, inflammation, stress, and lifespan etc.

Islamic fasting does not lower cognition level of fasting in healthy subjects as reported in our earlier study on healthy subjects. ${ }^{3}$ In our present study, Ramadan fasting does not negatively affect immune system of healthy fasting individuals rather it is improved (Unpublished data). In Ramadan the total energy consumption is not affected, however, protein and fat consumption is increased whereas other studies reports that the total caloric intake during Ramadan is not decreased and food consumption shows a significant decrease in carbohydrate intakes at the expense of fats and protein. ${ }^{4}$ During fasting significant reduction in the body weights of normal \& obese both male \& female subjects are observed and the basal metabolic Index (BMI) of normal \& obese both male \& female subjects' remains unchanged. Most importantly there is significant reduction in the waist to hip ratios of normal \& obese both male \& female subjects. ${ }^{5}$ The bioelectrical impedance (BIA) results show remarkable changes (most appropriately adjustments) in normal \& obese subjects. ${ }^{5}$ The important thing in Ramadan fasting which is observed in relation to cholesterol is the ratios of serum total-cholesterol and HDL-cholesterol which is improved in normal \& obese subjects in both sexes. ${ }^{5,6}$

There are emerging evidences in the contemporary literature that Islamic fasting and also other types of fasting do have beneficial effect(s) on the health of the fasting peoples. It is believed that during the year before fasting month begins, there are continuous metabolic changes in the body which are considered as risk factors for diseases are counter balanced in the month of Ramadan fasting and the effect may persist after the Ramadan. ${ }^{7}$ The healthier effect takes place, is more pronounced in women at younger age due to the reduction of intraabdominal fat which might be attributed to their activity (alertness). ${ }^{8}$ The beneficial effect of physical and biochemical changes happened during Ramadan fasting could be anti-depression ${ }^{5,9}$. However, the fasting strategy cannot be generalized in all kinds of physical and health status and awareness is required. ${ }^{10}$ It may produce ill effects in certain disease. ${ }^{11,12}$ Therefore, in Quran Allah Subhanahu Wa Ta'ala Say's that "Fasting is for a fixed number of days, but if any of you is ill, or on a journey, the prescribed number (missed) should be made up..." (Al-Qur'an, 2:184). No negative water balance during fasting is observed in healthy individuals. ${ }^{5,13}$ When pregnant mothers fast the growth indices of newborn babies are not affected. ${ }^{14,15}$ However, the aforementioned findings are contradictory to the results reported in an article of Almond and Mazumder. ${ }^{16}$ Furthermore, breast-feeding mother's (exclusively breast-fed infants) growth parameters are not affected ${ }^{17}$ and does not affect composition of breast milk. However, the nutritional status of lactating women might be affected. ${ }^{18}$ Fasting has a reducing effect on inflammation, waist circumference ${ }^{19}$ and heart diseases. ${ }^{20}$ The waist circumference is reduced during Islamic fasting of Ramadan and is more pronounced in the male compared to the female fasting Muslims. ${ }^{21}$ During Islamic fasting weight 
reduction is achieved through fat loss and associated with age and sex. ${ }^{22}$ According to Memari, et al. ${ }^{23}$ Ramadan fasting affect body composition, but not physical performance in female athletes with the reduction of blood glucose accompanied by a reduction in insulin concentration. Another study conducted by Haouari-Oukerro et al. ${ }^{24}$ reports that plasma triglycerides decreases with no change in total cholesterol and an increase in HDL-C against LDL-c indicative of positive improvements in blood lipid profile. Fasting in female volunteers showed improvement in lipid profile pattern which is an anti-atherogenic response. ${ }^{25}$ The Biblicalbased Daniel fasting has also been reported to have several health benefits including improvement in blood pressure, lipids profile, and insulin sensitivity etc. ${ }^{26}$ In prediabetics fasting can improve lipid profile and therefore may be protective against cardiovascular diseases. ${ }^{27}$

As mentioned earlier, that Islamic fasting does not lower cognition level of fasting individuals. This suggest that the performance in terms of memory and problem solving is not affected by Ramadan fasting. However, the effect of fasting on cognition is heterogeneous and performance in functions is better in the morning, and declining in the late afternoon. ${ }^{28}$ Some researchers suggest that fasting may not have adverse effect on specific cognitive performances ${ }^{29}$ and might be associated with significant changes in cognition due to a drop in diastolic blood pressure in healthy subjects. ${ }^{30}$ Furthermore, Farooq, et al. ${ }^{31}$ reported that fasting is associated with significant changes in sleep patterns and reductions in attention. In the fasting month, the duration of sleep is reduced compared to non-Ramadan days and the bed time is delayed in some cases by one and half hours during night but this delay is overcome by day time sleeping. ${ }^{32,33}$ There are controversial reports that sleep loss results in poor work performance of tasks requiring cognition and decrease is proportional the amount of sleep lost. ${ }^{34,35}$ The change induced by Ramadan fasting to the pattern of cognition is probably age dependent. In young individuals, there is improvement in the alertness and slight changes in the sleep loss. ${ }^{3}$ During Ramadan the pattern of physical activities is altered which have positive effect on health. From these studies, we infer that the level of cognition of the fasting individuals is not affected and it is advisable for sporting to enhance fluid intakes during Sohar (early breakfast). 3,4,28,29 There have been various other factors which may influence the cognition in fasting. The shift in food intake and disruption of sleep patterns affect actual and perceived physical performance of players. ${ }^{36}$ In some cases behavioral changes, marked by an increased irritability ${ }^{37}$ and a decrease in subjective alertness ${ }^{38}$ have been attributed to the abstention from nicotine and coffee. ${ }^{37}$ There is also evidence that performance and security at work are impaired. Traffic accidents increase ${ }^{39}$ with reduce learning performance ${ }^{40}$ and reduce muscular force. ${ }^{41,42}$ According to Ali and $\mathrm{Amir}^{43}$, fasting is likely to reduce cognitive function because of the physical fatigue that it induces in some people. We know that fasting is a condition in which there is a temporary lack of glucose intake to the body. Therefore it is logical to assume that human have reduce cognitive function when fasting. ${ }^{44}$

Ramadan fasting does not negatively affect immune system of healthy fasting individuals rather it is improved. Fasting during the month of Ramadan with regular physical activity causes positive alterations in hematological-biochemical indices. ${ }^{45,46}$ Ramadan fasting decreases the inflammation, pro-inflammatory cytokines IL-1b, IL6 , tumor necrosis factor. ${ }^{47}$ The beneficial effect of physical and biochemical changes happened during Ramadan fasting, can also be useful for the stressed individuals. ${ }^{4,5}$

The daily food consumption is not very much affected during the holy month of Ramadan and this requires Muslim to alter the timing of food and fluid intakes. As such, there are no restrictions on the quantity or type of foods that can be consumed during the night provided it is halal. Ramadan fasting involves a shift in the pattern of intake from daytime to the hours of darkness; therefore, eating pattern during Ramadan is different.

During Ramadan the total energy consumption is not affected, however, protein and fat consumption is increased whereas other studies reports that the total caloric intake during Ramadan is not decreased and food consumption shown increased intakes of fats and protein at the expense significant decrease in carbohydrate intakes. ${ }^{24}$ Contrary to these studies Khaled and Belbraouet ${ }^{48}$ observed significant decrease in total energy intakes during Ramadan and an increase in fat and proteins containing food. These studies infer that the total energy consumption is not reduced and there is increased intake of fat in place of carbohydrates. Therefore it can be concluded that in fasting people tend to consume more fat and protein containing foods.

Ramadan fasting leads to weight and fat mass reductions through changes in body composition and these changes vary depending on age and sex. ${ }^{22}$ It has varied impact on different individuals and is highly dependent on habits and the season that Ramadan occurs in. ${ }^{49}$ According to Fahrial Syam , et. al. ${ }^{50}$ weight loss in Ramadan fasting is a temporary effect and is regained within one month after fasting. Ramadan fasting can effectively change body weight along with some biochemical parameters in healthy subjects. ${ }^{51}$ It increases the concentration of Total-c, HDL-C and decreases LDL$\mathrm{C}$ in the blood of fasting individuals. ${ }^{52}$ Therefore, it is effective in ameliorating $\mathrm{HDL}-\mathrm{C}$, and its ratios with the rest of the fractions ${ }^{53}$. In general, physical and biochemical changes induced by Ramadan fasting are useful to various individuals. ${ }^{4,9}$ Similarly, there is a positive effect on body weight which happened due to loss of fat deposits; however, the 
reduction varies $54,55,56,57$ from person to person. Some individuals may put on body weight during Ramadan if they are careless in total calories intake (Frost \& Pirani, 1987). ${ }^{58}$ The body composition do not change however there is shift of fluids between intra and extra cellular fluid which happens at the cost of body fat mobilization. ${ }^{59}$ During Ramadan the activities pattern changes both in male and female and is age dependent. ${ }^{22}$ The modified food frequency and eating pattern during Ramadan results changes in total energy consumptions and weight losses in obese individuals. 4, 60,61,62 Some studies suggests that during fasting there is restriction on the intake of fat therefore, there is lowering blood lipids concentration in the fasting people. ${ }^{4,60,61,62}$ Reduction in blood lipids seems to be associated with the composition of diet ${ }^{63}$ and reduce energy intake. ${ }^{64}$

\section{CONCLUSIONS}

Apart from spiritual effects, Islamic fasting could be a useful tool for the improvement of health. Cognition of healthy subjects is not affected in fasting. Similarly, energy and macronutrients intakes are not affected as well rather fasting cause changes in the eating pattern and timing only. Furthermore, it reduces body weight, BMI and waist to hip ratio in normal and obese subjects in both sexes. It appears that the reduction take place due to the increase in fat free mass and increased total body water (positive association) and reduced fat contents with increased body water (negative association). Above all fasting cause reduction in blood glucose with improvement in HDL \& total cholesterol ratios which is of clinical significance.

\section{REFERENCES}

1. (Akhtar,http://www.soundvision.com/article/ the-spiritual-and-health-benefits-of-ramadanfasting (Accessed on August 3, 2016).

2. Athar, S (1984)."Therapeutic Benefits of Ramadan Fasting," IslamicHorizon.

3. Yasin WM, Khattak MMAK, Mamat NM et al. Does religious fasting affect cognitive performance?. Nutr \& Food Sci 2013; 43 (5), 483-489.

4. Khattak MMA K, Mamat NM, Abu Bakar WAM et al. Does religious fasting affect energy and macro-nutrients intakes? Nutr \& Food Sci 2013; 43 (3), 254-260.

5. Khattak MMAK, Bakar IA and Yiem L, Religious Fasting Increase Fat Free Mass (FFM) and Reduce Abdominal Obesity. Nutr Food Sci 2012; 42(2):87-96.

6. Khattak MMAK, Bakar IA and Yiem L, Religious Fasting: An Alternative Approach to Improve Hyperlipidaemia. Nutr Food Sci 2011; 42(4):241 249.

7. Sarraf-Zadegan N, Atashi M, Naderi GA, et al. The effect of fasting in ramadan on the values and interrelations between biochemical, coagulation and hematological factors. Ann Saudi Med 2000; 20,377-381.

8. Yucel A, Degirmenci B, Acar M, et al. The effect of fasting month of Ramadan on the abdominal fat distribution: Assessment by Computed Tomography Tohoku J. Exp. Med. 2004; 204, 179 $-187$.

9. Akuchekian S, Ebrahimi A, Alvandian S, Effect of the Holy Month of Ramadan on Coping Strategies. J Res Med 2004; Sci. 2: 65-68.

10. Azwany N, Ismail AA, Mohammad WBW, et al. Effect of ramadan fasting on glycemic status of type 2 diabetic patients in Northern Malaysia. The Inter Med J 2003 2(2):

11. Masahiro T, and Kanehisa M, Effects of Ramadan Fasting on the Health of Muslims. Japanese J Hygiene 2004; 54(4):592-596.

12. Al-Arouj M, Bouguerra R, Buse J, Hafez S, et al. Recommendations for management of diabetes during Ramadan. Diabetes Care 2005; 28, 23052311.

13. Leiper JB, Molla AM and Molla AM, Effects on health of fluid restriction during fasting in Ramadan. Euro. J Clin Nutr 2003; 7:S30-S38.

14. Shahgheibi S, Ghadery E, Pauladi A, et al. Effect of fasting during the third trimester of pregnancy neonatal growth indices. Annals of Alquds Medicine (2005) 2:58-62.

15. Arab M, and Nasrollahi S Interrelation of Ramadan fasting and birth weight. Med J Islamic Acad Sci. 2001; 14:3, 91-95.

16. Almond D, Mazumder, B, The Effects of maternal Fasting During Ramadan on Birth and Adult Outcomes. http://www.nber.org/ almond/ramadan_abstract.pdf.2008; Accessed on August 3, 2017.

17. Khoshdel A, Najafi M, Kheiri S, et al. Impact of Maternal Ramadan Fasting on Growth Parameters in exclusively Breast-fed Infants. Iran J Pediatr 2007; 17 (4): 345-352.

18. Rakicioğlu N, Samur G, Topçu A, The effect of Ramadan on maternal nutrition and composition of breast milk. Pediatrics Inter 2008;48(3):278283.

19. Hamdy EA, Attia S and Ghonna R, Effects of the Fast of Ramadan on Endothelial Function and High-Sensitivity C - Reactive Protein in Newly Diagnosed Type 2 Diabetic Patients. Kuwait Med J 2008; 40, 53-58.

20. Malik GM, Mubarik M and Hussain T, Ramadan fasting "Effects on health and disease". J.K. Practitioner 1995; 2(1): 19-21.

21. Saleh SA, Elsharouni SA, Cherian B, et al. Effects of Ramadan fasting on waist circumference, blood pressure, lipid profile, and blood sugar on a sample of healthy Kuwaiti men and women. Mal J Nutr 2005; 11:43-150.

22. Norouzy A, Salehi M, Philippou E et al. Changes in body weight, dietary intake and activity pattern of adolescents during Ramadan. Malaysian J Nutr 1996; 2:1-10.

23. Memari AH, Kordi R, Panahi N, et al. Effect of ramadan fasting on body composition and physical performance in female athletes. Asian $\mathrm{J}$ Sports Med 2011; 2(3):161-6.

24. Haouari-Oukerro F, Ben-Attia M, Kaâbachi, N, et al. Ramadan fasting influences on food intake consumption sleep schedule, body weight and some plasma parameters in healthy fasting 
volunteers. African J of Biotech 2013; 12(21): 3327-3332.

25. Akhtaruzzaman M, Hoque N Choudhury MBK, et al. Effect of Ramadan Fasting on Serum Lipid Profile of Bangladeshi Female Volunteers Bangladesh J Med Biochem 2014; 7(2): 47-51.

26. Trepanowski JF and Bloomer RJ The impact of religious fasting on human health. Nutr $\mathrm{J} 2010$; 9(57): 1-9.

27. http://blogs.nature.com/ houseofwisdom/2014/06/ramadan-fasting-could -help-protect-from-diabetes-badcholesterol.html (Accessed in August 2017).Background:

28. Tian HH, Aziz AR, Png W, Wahid MF, et al. Effects of fasting during Ramadan month on cognitive function in muslim athletes. Asian $\mathrm{J}$ Sports Med 2011; 2(3):145-53.

29. Najafabadi GM, Nikoukar LR, Memari A, et al. Does Ramadan Fasting Adversely Affect Cognitive Function in Young Females? Scientifica, 2015:1-6.

30. Alsharidah, AM, Murtaza, G, Alsharidah, M.M. and Bashir, S.(2016). Fasting in Ramadan affects cognitive and physiological function in normal subjects (Pilot Study). Neuroscience \& Medicine, 7, 60-65. Accessed on August 3, 2017.

31. Farooq A, Herrera CP, Almudahka F, et al. A prospective study of the physiological and neurobehavioral effects of Ramadan fasting in preteen and teenage boys. J Acad Nutr and Dietet, 2015; 115 (6), 889-897

32. BaHammam A Assessment of sleep patterns, daytime sleepiness, and chronotype during Ramadan in fasting and nonfasting individuals. Saudi Med J 2005; 26:616-22.

33. BaHammam A The effects of fasting during Ramadan on sleep architecture, daytime sleepiness, and sleep pattern. Sleep Biol Rhythm 2004; 2:135-43.

34. Reilly T, Waterhouse J, Sports performance: is there evidence that the body clock plays a role? Eur J Appl Physiol 2009;106(3):321-332.

35. Margolis SA and Reed RL, Effect of religious practices of Ramadan on sleep and perceived sleepiness of medical students. Teaching and Learning in Medicine 2004; 16(2):145-149.

36. Zerguini Y, Kirkendall D, Junge A et al. Impact of Ramadan on physical performance in professional soccer players. Brit. J Sports Med:2007;41(6),

:http: / / www.bmjjournals.comAccessed on August 3, 2017).

37. Kadri N, Tilane A, El Batal M, et al. Irritability during the month of Ramadan. Psychosomatic Medicine 2000; 662, 280-285.

38. Roky R, Iraki L, HajKhlifa R, et al. Day time alertness, mood, psychomotor performances, and oral temperature during Ramadan intermittent fasting. Ann Nutr and Meta 2000; 44,101-107.

39. Shanks NJ, Ansari M, Al-Kalai D Road traffic accident in Saudi Arabia. Public Health, 1994; 108: 27-34.

40. Afifi ZE Daily practices study performance and health during the Ramadan fast. J Royal Soc Health 1997; 117, 231-235.

41. Bigard AX, Boussif $M$, Chalabi $H$, et al. Alterations in muscle performance and orthostatic tolerance during Ramadan. Aviat Space Environ Med 1998; 69, 341-346.

42. Boussif M, Bigard AX, Chalabi $\mathrm{H}$ et al. Effets du Ramadan sur les performances physiques de pilotes d'avions de combat. Me'd Ae' ronaut Spatiale, 1996; 5: 166-174.

43. Ali MR, Amir T, Effects of fasting on visual flicker fusion. Percept Mot Skills 1989; 69:62731.

44. Rochmyaningsih D, Effect of Monday-Thursday Fasting on Working Memory of Adult Human. The J. Young Investigators:2009; 19(14): 1-8.

45. Attarzadeh-Hosseini SR, and Hejazi $\mathrm{K}$ The effects of Ramadan fasting and physical activity on blood hematological-biochemical parameters. Iran J Basic Med Sci.2013; 16(7):845-9.

46. Attarzadeh-Hosseini SR, and Hejazi K A review of Ramadan fasting and regular physical activity on metabolic syndrome indices. J. fasting and Health. http://jfh.mums.ac.ir/article_6424_881.html (Accessed in August 2017).

47. Meo SA, Hassan A, Physiological changes during fasting in Ramadan. J Pak Med Assoc 2015; 65(5 Suppl 1):S6-S14.

48. Khaled BM and Belbraouet S, Effect of Ramadan fasting on anthropometric parameters and food consumption in 276 type 2 diabetic obese women. Int J Diabetes Dev Ctries 2009; 29(2): 62-68.

49. Mazidi O, Karimi E, Rezaee P, et al. The Effects of Ramadan Fasting on Body Composition. Shiraz E-Med J 2014;15(1): e19733.

50. Fahrial Syam A, Suryani Sobur C, Abdullah M, et al. Ramadan Fasting Decreases Body Fat but Not Protein MassInt J Endocrinol Metab. 2016; 14(1): e29687.

51. Kul S, Savas E, Abidin O“ ztu“rk Z et al. Karadag G, Does Ramadan fasting alter body weight and blood lipids and fasting blood glucose in a healthy population? A Metaanalysis. J Relig Health (2014); 53:929-942.

52. Pirsaheb S, Pasdar Y, Navabi SJ, et al. Fasting Consequences during Ramadan on lipid Profile and Dietary Patterns. Asia Oceania. J Nucl Med Biol. 2013; 1(2):6-12.

53. Akaberi A, Golshan A, Moojdekanloo M, et al. Does fasting in Ramadan ameliorate lipid profile? A prospective observational study. Pak J Med Sci. 2004; 30(4): 708-711.

54. Husain R, Duncan MT, Cheah SH, et al. Effects of fasting in Ramadan on Tropical Asiatic Moslems. Brit J Nutr 1987; 58, 41-48.

55. Hallak MH and Nomani MZA. Body weight loss and changes in blood lipid levels in normal men on hypocaloric diets during Ramadan fasting. Am J Clin Nutr 1998; 48:1197-210.

56. Sweileh N, Schnitzler A, Hunter GR et al. Body composition and energy metabolism in resting 
and exercising Muslims during Ramadan fast. J. Sports Med. Phys. Fitness 1992; 72, 156-163. Accessed on August 3, 2017.

57. Ramadan J, Telahoun G, Al-Zaid NS, et al. Response to exercise, fluid, and energy balances during Ramadan in sedentary and active males. Nutr 1999;15, 735-739.

58. Frost $G$, and Pirani S, Meal frequency and nutritional intake during Ramadan: a pilot study. Hum Nutr Appl Nutr 1987; 41, 47-50.

59. El Ati J, Beji C, and Danguir J, Increased fat oxidation during Ramadan fasting in healthy women: an adaptive mechanism for bodyweight maintenance. Am J Clin Nutr 1995; 62, 302-307.

60. Furuncuoglu $\mathrm{Y}$, Karaca E, Aras S et al. Metabolic, biochemical and psychiatric alterations in healthy subjects during Ramadan. Pak J Nutr 2007; 6: 209-211.

61. Qujeq D, Bijani K, Kalavi K, Eeffects of Ramadan fasting on serum low-density and highdensity lipoprotein-cholesterol concentrations Ann Saudi Med 2002; 22(5-6): 297-299.

62. Asgary S, Aghaei F, Naderi G, et al. Effects of ramadan fasting on lipid peroxidation, serum lipoproteins and fasting blood sugar. Med J Islamic Acad Sci. 2000; 13, 35-38.

63. Mohmoud $\mathrm{K}$ and Mansi S, Study the Effects of Ramadan Fasting on the Serum Glucose and Lipid Profile among Healthy Jordanian Students. Amer J Appl Sci 2007;4,565-569.

64. Afrasiabi A Hassanzadeh S, Sattarivand R, et al. Effects of Ramadan fasting on serum lipid profiles on 2 hyperlipidemic groups with or without diet pattern. Saudi Med J 2003; 24(1):23-6. 